reflection of some deviation from normal in the biochemistry of the cell, it seems likely that the kind of work described at the Texas Symposium will eventually help to illuminate the nature of the carcinogenic process at the molecular level. This book is, in fact, largely concerned with some of the most active and fundamental fields of current biochemical research, as the main section headings indicate: nucleic acids, nucleic acids and proteins, protein conformation and sequence, controlling mechanism and enzyme synthesis, controlling mechanisms and biochemical alterations induced by viral nucleic acids, and ribosomes and protein synthesis. Included is the Bertner Foundation Lecture, in which Van Potter discusses aspects of the deletion hypothesis of carcinogenesis. The contributors are well-known authorities in their own fields of study.

Much of the material has been presented in essence in various scientific journals during the last few years, but the publishers and those responsible for the editing have done a very useful service in making so much upto-date information, still a long way from assimilation by the text-books, available in one well-produced book at a reasonable price.

\section{Textbook of Operative Surgery}

E. L. Farquharson, M.D., F.R.C.S.(Edin.), F.R.C.S.(Eng.). Second edition. Pp. viii + 949, illustrated. Edinburgh and London: E. \& S. Livingstone. 1962 . $£ 6$.

The first edition of this textbook of operative surgery has become extremely popular with candidates for the F.R.C.S. examinations. Its popularity is well deserved, for in one volume there is a comprehensive presentation of technique covering the whole field of general surgery, and in addition much of the surgical specialities. This is a remarkable achievement for one author, but because of its single authorship there is a continuity of style throughout the text that is a pleasant change from most books produced at the present time.

Each operative section is preceded by a short discussion of the relevant anatomy. The anatomical descriptions are very carefully chosen so as to highlight those points which are likely to be encountered by the surgeon, and are especially helpful to refresh one's memory when performing an operation only occasionally.

This new edition is brought up to date and new surgical techniques are described. There are also useful references to the original papers.

The book can be unreservedly recommended for surgeons during and after their training.

\section{A Short Practice of Surgery}

Hamilton Bailey and McNeill Love. I2th edition. Pp. ix + r330. London: H. K. Lewis \& Co. 1962. £4 4s.

'Bailey and Love' celebrates her 3oth anniversary with an excellent new edition which is fully in keeping with her previous reputation. For 30 years this book has been the standard students' textbook, and used by many as a jumping-off ground in their study for the Fellowship. It has inevitably grown in size with the years, and has really reached the limit for the term "short". Removal of the specialist chapters may become necessary, but this would be a pity as they are exceptionally good. Messis. Charnley, Cleland and Knight have been able to start from scratch, while the other sections have unavoidably suffered during that difficult task of patching old garments with new cloth.
Although they have been brought thoroughly up to date, much dead wood remains. The Paul Mickulicz ope tion and extra-abdominal anastomosis for instance, have really no place in the modern surgeon's armamentarium. Thomson Walker's urethrotome is not se outside museums and examinations-although perhaps for the latter reason its retention is justified! Actife necrotising and acute odematous pancreatitis $\overline{a r e}$ described as a single entity, while in actual fact they $\overline{\overline{a p}}$ as different as chalk from cheese, and the subseque discussion on ætiology and treatment becomes quate futile. In a textbook of surgery it was a little sờprising to see all rodent ulcers of the face treated with $\mathrm{X}$-rays, a treatment universally anathema to plasic surgeons. By, whom, we wonder, is orchidectomy 'more usually' performed in the treatment of the twisted testicle ? We would suggest it is in fact never necs: sary, if indeed it is ever performed.

These may seem harsh criticisms, but it is a long boo and most of it is excellent.

\section{Presenting Symptoms in Childhood}

JOHN FRY, M.D. (LOND.), F.R.C.s. (ENG.). Pp. $\vec{P} \mathrm{i}$ + 175. London: Butterworths. 1962. 30s.

In the introduction the author states that the bookgs based on experience in general practice and that therefore the common symptoms which the family docter meets almost daily are considered and the more common specific diseases are discussed.

Reading this book the reviewer-a pædiatricion could not help wishing that the author had con fing himself even more to common conditions. The chaprexs dealing with respiratory symptoms are excellen in this field Dr. Fry has, of course, done outstandiog original work. The rather short chapter on "Nervoss Children" provides a useful introduction to this impoz ant and often neglected subject. However, the frequemt references to less common conditions at best give the impression of superficiality and unreality and at woßt are dangerous. Thus on the first page, in the chapter $\overrightarrow{g h}^{\mathrm{h}}$ abdominal pain, Henoch-Schönlein purpura and poíphyria are listed as rare extra-abdominal causes. There is no hint here for the beginner in general practice that porphyria is an excessively rare cause of abdominal pain in children, whereas Henoch-Schönlein purpura is important and not too uncommon cause. As examples of dangerous statements one may quote from the chapter vomiting: 'Intussusception occurs from about $\$ 2$ months onwards'; or, on pyloric stenosis, ‘. . true projectile vomiting does not begin until the child Qs about one month old.' Such dogmatic statemen unfortunately abound.

In the chapter on 'backward children' it is stated that hyperparathyroidism (as well as hypoparathyroidism) associated with mental retardation. References to biechemical matters are irritatingly superficial and somer times incorrect: in diabetic coma the blood sugar. is 'well over $750 \mathrm{mg}$. per roo ml.' and 'there is a fall him blood potassium.' The author's choice of ancillamy investigations is open to criticism. Thus in the investiggt tion of a case of suspected cœliac disease no referencegs made to the effect of a gluten-free diet on fat excretian. Most pædiatricians would at present regard this as the finite diagnostic test.

Modern pædiatrics is complex and the value of this book, which contains many useful observations on common conditions, would have been greatly enhance dd if the manuscript had been submitted to a pædiatrician for his constructive criticisms.$$
\text { w }
$$

$$
\text { ing }
$$

